\title{
MANAGEMENT MODEL OF RAILWAY STATIONS WITH THE FOCUS ON SUSTAINABLE DEVELOPMENT OF PUBLIC TRANSPORT
}

\begin{abstract}
The article presents the assumptions of a modern management model of railway stations. In this model, the station is perceived as part of a multimodal hub which includes, besides the building used for passenger' check-in, also railway platforms, access routes and surrounding infrastructure in the form of public transport stops and parking lots and other facilities. The authors point to the necessity of constructing interchange nodes integrating the station with the urban tissue. The article discusses the issue of categorizing stations and standardizing services at railway stations to best meet the needs of users. The authors point out that innovative solutions are the key condition for improving the quality of stations. The station design process should be linked to the current review and the search for innovations in the field of materials, energy, ICT, architecture and passenger services. An interesting direction for the development of railway stations are services related to the sharing economy, such as co-working, car-sharing and bike-sharing. The article also presents the concept of creating an integrated entity managing the passenger station area, a model of solutions in other European countries.

Keywords: railway stations, interchange nodes, multimodal hubs, categorization, standard of passenger services, innovations, sharing economy, integrated management
\end{abstract}

\section{Introduction}

Changing mobility trends pose new challenges for railway stations. Individual motorization is developing dynamically, as well as forms of collective transport 
that are competitive to rail - bus and air connections. In the years 2000-2016, the number of cars per 1.000 inhabitants in Poland increased from 261 to 564, i.e. by $116 \%{ }^{1}$. The number of air transport passengers on domestic routes increased from 875.000 people in 2010 to 1.3 million people in $2016^{2}$, i.e. by more than $50 \%$, while one of the leading long-distance bus carriers within 65 months of the start of operations carried 20 million passengers ${ }^{3}$.

There is also an increase in alternative forms of movement, e.g. shared journeys, car rental systems and city bikes. All these phenomena mean that maintaining the attractiveness of the railway requires continuous improvement of the quality of services at railway stations and closer integration of the station with the surroundings. The railway station should encourage the use of public transport, providing the necessary comfort and enabling efficient change between modes of transport.

\section{The station as a multimodal hub}

Conducted by the Polish State Railways (PKP S.A.) in 2014 survey of railway station users ${ }^{4}$ illustrates the perception of railway stations by passengers. The survey showed that under the slogan "railway station" the most commonly used is a transfer node connected with urban transport and long-distance bus transport. The visible border of the station is only public road. In general, Polish State Railways is responsible for the image of the entire area, including cash registers, ticket machines (regardless of the operators serving them), and even commercial services provided at the station.

The total travel time from the place of departure to the destination is, apart from the price, one of the most important criteria for choosing a way of moving. A private passenger car has a natural advantage over collective transport, allowing for a direct passage from door to door. From the point of view of the total travel time, the functionality of the station, as a transfer point between various modes of transport and the potential "moderator" of travel, significantly affects the attractiveness of the entire logistic collective transport chain. Travel by train requires the use of at least two passenger stations, which is why the quality of transfer points can be a decisive factor in the choice of rail transport relative to the individual. The railway station should, as far as possible, eliminate the inconvenience of transferring, that is minimize the time and passenger effort devoted to this activity. The answer is the construction of communication and interchange centers (multimodal hubs) enabling a quick, convenient and economically justified change, ensuring comfort and safety, as well as providing additional services.

A correctly designed interchange node ensures the integration of the railway station with collective transport (tram, bus) and individual. The optimal location

\footnotetext{
Rocznik statystyczny Rzeczypospolitej Polskiej 2017, Central Statistical Office, Warsaw 2017, p. 66-67. Ibidem, p. 545.

3 Public Transport Portal, http://www.transport-publiczny.pl/wiadomosci/polski-bus-od-startu-przewiozl-20-mln-pasazerow-53504.html (access: 20.02.2018).

4 Jakościowe badanie eksploracyjne użytkowników dworców, Millward Brown, Warsaw 2014.
} 
of stops, as well as park \& ride, kiss \& ride and bicycle parkings located near the station are important. A desirable solution is to create nodes with priority for pedestrian traffic, so that they are safe and comfortable to use. The determinant of this priority is, for example, the lack of barriers in the form of streets, which pedestrian must pass on the way from the station to the public transport stop. Station forecourts should become, in principle, zones of safe pedestrian traffic and limited or excluded car traffic, which are mainly accessible to public transport vehicles. An additional element that increases the level of integration of means of public transport may be a common passenger information system, allowing, for example, access to urban transport timetables at the railway station.

An important component of the standard resulting from legal regulations is also the implementation of the TSI PRM standards on the accessibility of rail for the disabled and with reduced mobility ${ }^{5}$. The solutions used at railway station buildings should correspond to the concept of universal design, which according to the definition is to serve as many users as possible, without the need for additional improvements ${ }^{6}$. Due to the binding legal regulations, as well as the image of infrastructure managers, PKP and PKP PLK work together to ensure proper access to passenger station facilities (including stations), services and information for everybody, both disabled and not having mobility restrictions.

An example of the implementation of a modern interchange is Marburg in Hesse (Germany) - a city of 70000 inhabitants, which was chosen the German Railway Station of the Year 2015 in the Allianz pro Schiene plebiscite ${ }^{7}$. The station was integrated with the surroundings and allows convenient transfers to buses, as well as access to and leaving the bicycle or car. A restricted traffic zone was created in front of the building with a maximum speed of $20 \mathrm{~km} / \mathrm{h}$. The station building itself was fully adapted to the needs of people with reduced mobility by means of ramps, mechanical devices and facilities for the blind.

One of the most important aspects related to the implementation of investments at railway stations is cooperation with external entities that have both indirect and direct impact on their implementation and are their beneficiaries. It is necessary to plan the implementation of the investment taking into account the plans of the national infrastructure manager of PKP PLK, which not only manages rail tracks, but also elements of passenger infrastructure, i.e. platforms and routes to access them. Only this type of cooperation will ensure the elimination of the problem of non-uniform standard in the area of the passenger station. In addition, PKP Group undertakes cooperation with local government units and private entities being the owners of the areas around the station. Its purpose is to extend the scope of works including the construction of integrated transfer nodes, including stops

5 COMMISSION REGULATION (EU) No 1300/2014 of 18 November 2014 on the technical specifications for interoperability relating to the availability of the Union's rail system for people with disabilities and persons with reduced mobility ( $\mathrm{L}$ series of journals in the European Union No 356 from 12 December 2014).

6 Projektowanie uniwersalne. Ekspertyza w zakresie dostępności kolejowych obiektów obstugi podróżnych z niepetnosprawnościami oraz ograniczonq możliwościq poruszania się, Office of Rail Transport, Warsaw 2017.

7 Allianz pro Schiene website, https://www.allianz-pro-schiene.de/presse/pressemitteilungen/marburg-und-obstfelderschmiedelichtenhain-sind-sieger/ (access: 20.02.2018). 
and parking lots, and the adaptation of the urban fabric, which is the immediate surroundings of the railway station, to new standards and needs of travelers.

\section{Categorization and standardization of stations}

The survey of railway station users was the starting point for the development and implementation of a new categorization of stations and the related service standard. Introduced by PKP in 2015, the new categorization structure (Premium, Voivodeship, Regional, Agglomeration, Local and Tourist stations) is based on pro-passenger criteria. It replaced the earlier technical categorization (A, B, C, D, E). The new division of stations takes into account the role played by individual objects in passenger transport and takes into account factors such as the location and importance of the communication node, the leading type of railway traffic, users' cross-section, as well as service and social functions. The operating categorization of stations and selected factors determining the assignment to particular categories are shown in Table 1.

Table 1. Categorization of railway stations of PKP

\begin{tabular}{|c|c|c|c|c|c|c|}
\hline & Premium & Voivodeship & $\begin{array}{l}\text { Agglomera- } \\
\text { tion }\end{array}$ & Regional & Local & Tourist \\
\hline Location & \multicolumn{2}{|l|}{ big city } & $\begin{array}{l}\text { up to } 50 \mathrm{~km} \\
\text { from the } \\
\text { center of } \\
\text { a large city }\end{array}$ & $\begin{array}{l}\text { medium or } \\
\text { small city }\end{array}$ & $\begin{array}{l}\text { small town } \\
\text { or village }\end{array}$ & $\begin{array}{l}\text { a place } \\
\text { of tourist } \\
\text { importance }\end{array}$ \\
\hline Traffic Type & \multicolumn{2}{|c|}{ long-distance (high) } & $\begin{array}{l}\text { agglomera- } \\
\text { tion }\end{array}$ & \multicolumn{2}{|c|}{$\begin{array}{l}\text { long-distance (low), } \\
\text { regional }\end{array}$} & tourist \\
\hline $\begin{array}{l}\text { Communi- } \\
\text { cation Node }\end{array}$ & $\begin{array}{l}\text { at the coun- } \\
\text { try level }\end{array}$ & $\begin{array}{l}\text { at the inter- } \\
\text { voivodeship } \\
\text { level }\end{array}$ & $\begin{array}{l}\text { at the level } \\
\text { of agglomer- } \\
\text { ation }\end{array}$ & $\begin{array}{l}\text { at the } \\
\text { voivodeship } \\
\text { level }\end{array}$ & $\begin{array}{l}\text { low traffic } \\
\text { potential }\end{array}$ & $\begin{array}{l}\text { important } \\
\text { seasonally }\end{array}$ \\
\hline $\begin{array}{l}\text { Station } \\
\text { Users }\end{array}$ & \multicolumn{2}{|c|}{$\begin{array}{l}\text { wide range of users } \\
\text { and motivation }\end{array}$} & \multicolumn{3}{|c|}{$\begin{array}{l}\text { a permanent group of people (regular } \\
\text { commuting, schools - usually a short } \\
\text { time at the station) }\end{array}$} & $\begin{array}{l}\text { high tourist } \\
\text { traffic } \\
\text { (seasonal) }\end{array}$ \\
\hline $\begin{array}{l}\text { Services, } \\
\text { Commercial } \\
\text { Functions }\end{array}$ & $\begin{array}{l}\text { maximi- } \\
\text { zation } \\
\text { of com- } \\
\text { mercial } \\
\text { functions, } \\
\text { a wide } \\
\text { range } \\
\text { of services }\end{array}$ & $\begin{array}{l}\text { significant } \\
\text { commercial } \\
\text { functions, } \\
\text { a wide } \\
\text { range } \\
\text { of services }\end{array}$ & $\begin{array}{l}\text { no } \\
\text { significant } \\
\text { commercial } \\
\text { functions, } \\
\text { possible } \\
\text { additional } \\
\text { services }\end{array}$ & $\begin{array}{l}\text { the lack } \\
\text { of important } \\
\text { commercial } \\
\text { functions } \\
\text { is less } \\
\text { common, } \\
\text { the range } \\
\text { of services } \\
\text { depends } \\
\text { on the loca- } \\
\text { tion }\end{array}$ & $\begin{array}{l}\text { no } \\
\text { significant } \\
\text { commercial } \\
\text { functions, } \\
\text { minimal } \\
\text { range } \\
\text { of services }\end{array}$ & $\begin{array}{l}\text { special } \\
\text { user needs } \\
\text { resulting } \\
\text { from } \\
\text { less time } \\
\text { pressure }\end{array}$ \\
\hline Other & \multicolumn{2}{|c|}{$\begin{array}{l}\text { expectations regarding } \\
\text { the social function } \\
\text { of the station (meeting } \\
\text { place, cultural events) }\end{array}$} & - & - & - & $\begin{array}{l}\text { tourist } \\
\text { and cultural } \\
\text { functions }\end{array}$ \\
\hline
\end{tabular}

Source: own elaboration based on: internal materials of PKP 
For each station category, a package of services was defined, i.e. the target standard and a set of services that should be provided on a given site. It is a response to passenger needs that arise from the type of facility and the nature of the traffic. According to the survey results, over $80 \%$ of people arrive at the station within 30 minutes before the train departure ${ }^{8}$. However, there are differences between people arriving on a long-distance train and regional or agglomeration; for persons traveling on inter-voivodship trains, the trend of earlier arrival at the station is visible. For this reason, it is assumed that the scope of commercial functions performed by Agglomeration stations will be much lower than in the case of Premium or Voivodeship railway stations servicing significant long-distance traffic. In addition, variants of extending the service catalog within the concept of tailor-made services will be analyzed for each station. In addition to the minimum package of services, the organization will strive to implement commercial services that respond to the current diagnosis of the needs of people using the station in a given location. At the stage of commencement of project works for each station facility, actions are undertaken to diagnose the needs in the area of commercial space. Their diversity should correspond to the real needs of travelers and take into account the rational management of financial resources.

Achieving the target parameters of railway stations requires undertaking actions in the field of innovation, quality and accessibility of services as well as cooperation with external entities. Innovative solutions are a key condition for increasing the quality of stations. The station design process is linked to the ongoing review and search for innovations in the areas of materials, energy, ICT, architecture as well as passenger services. The currently updated catalog of innovative solutions is used in subsequent station projects.

In the course of work carried out by PKP innovations aimed at increasing the operational efficiency of stations are developed. The use of new technologies decreases operating costs and reduces the negative impact of the station building on the environment. One of such innovations is the intelligent Building Management System (BMS), which connects all installations at the station into one unit, allowing efficient and economical management of the entire facility from one place. The BMS controls the work parameters of individual devices, informs about problems and failures and also allows the settlement of media usage. Systematic implementation of other solutions is planned, e.g. the use of rainwater as water for flushing toilets, installation of energy-efficient LED lighting, photovoltaic cells, heat pumps and energy-saving gas furnaces, as well as the creation of green roofs. In place of oversized station buildings, it is envisaged, if local conditions allow, to build smaller, repeatable buildings with one standard of execution, while optimizing the surface.

The paths of obtaining innovative solutions take into account the possibilities of cooperation with units implementing tasks in the area of science, science and technology as well as innovation policy. In connection with the key project of innovative railway stations, PKP joined the work of the European Shift2Rail initiative. As part of the cooperation between PKP will conduct research in the field of "Improved

8 Badanie satysfakcji z podróży w pociagach PKP Intercity, report of the $6^{\text {th }}$ stage of the study, Millward Brown, Warsaw 2015, p. 317. 
Station Designs and Components" and "Crowd Management in High Capacity Stations". An important advantage of cooperation is the possibility of preferential use of research results carried out by other organizations participating in Shift2Rail.

In the areas of safety, comfort, ergonomics and IT, innovative activity is focused on acquiring ready-made solutions offered by innovative enterprises. One of the effects of such action was the implementation of an online sign language interpreter at the station's information points, which allows direct contact between the station employee and the person with a hearing impairment. An interesting trend from the point of view of innovative services connected with railway stations is the development of sharing services. Such services include co-working, which means sharing by a few or a dozen small companies one headquarters and work space, in order to reduce the fixed costs of operations. Due to its central location in relation to the city center, the station is an ideal place. Other sharing services include car and bicycle sharing systems, which are an alternative to owning your own car and a complement to public transport.

\section{Integrated management of the passenger station area}

In order to achieve the target standard of passenger services, the model of integrated management of a passenger station should be adopted. In accordance with the qualitative survey of railway stations earlier referred to, users perceive the station as one unit consisting of a hall, platforms, as well as tunnels, access roads, and parking lots. The present practice of managing stations by PKP Group revealed the imperfections of the adopted model, in which the responsibility for managing the station building, platforms and access routes is divided between the two companies: PKP and PKP PLK. Thanks to the cooperation of the Companies in previous years, selected services (e.g. cleaning) were standardized throughout the passenger area by conducting one proceeding and concluding joint contracts with contractors, however, there are still difficulties in coordinating investment and maintenance work, deepened by unclear responsibilities and duplication of competence.

In order to ensure high-quality passenger services, it is necessary to integrate them throughout the passenger station area, i.e. at the station building, platforms and access routes. The integration of services may take place through the consolidation of functions related to the management of passenger infrastructure (stations buildings, platforms, access routes), held separately until now by the companies of PKP and PKP PLK, as part of a specialized organizational unit that equipped with appropriate tools will be able to make decisions more efficiently and coordinate maintenance and investment works. The details of the functioning of such a structure in Poland, its competences, and the method of financing, require analyzes taking into account local Polish conditions. Organizational solutions involving integrated management of the passenger station are used in other European countries. In Germany, the specialized company DB Station \& Service manages the whole area of the passenger station and owns the station buildings. The owner of the platforms and routes of access to them is the railway infrastructure manager DB Netz, and DB 
Station \& Service manages these elements on his behalf, based on the use agreement (Nutzungsüberlassungsvertrag). A solution similar to the German one is used in France, where maintenance services in the whole passenger railway area are provided by a dedicated SNCF entity under the name SNCF Gares \& Connexions, partly commissioned by the SNCF Réseau railway infrastructure manager.

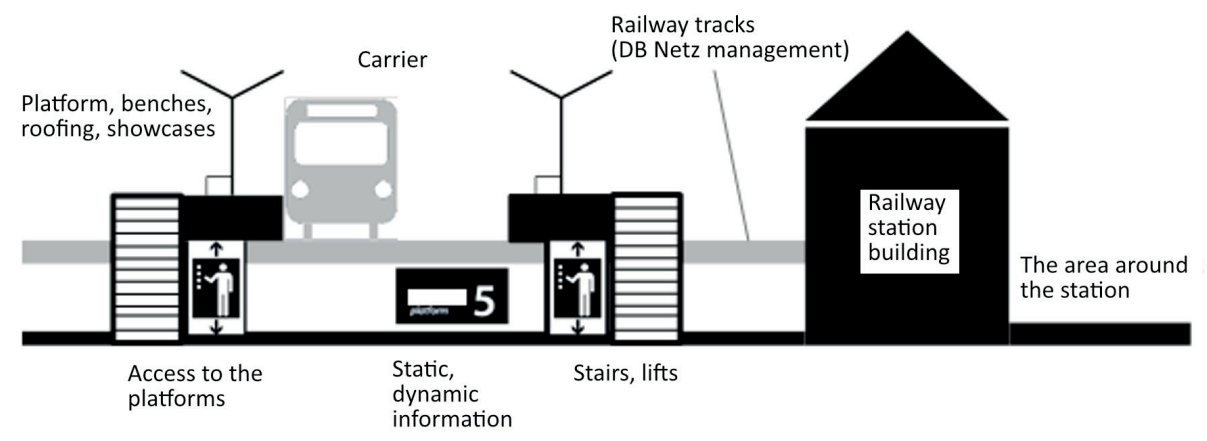

Ownership of DB Netz

Ownership of DB Station \& Service

Figure 1. Management of the passenger station and division of ownership in the German model (elements covered by integrated management are marked in black)

Source: own elaboration based on: We build and operate train stations!, DB Station \& Service AG presentation material, 2015

Integrated management allows planning, execution of investment and operating works, as part of a coherent process throughout the passenger service area. The integration of passenger station management in one hand will bring benefits both from the point of view of the quality of services and tangible cost synergy effects resulting, for example, from concluding one contract for various services and works performed by external companies, such as media supply, purchase of materials, repairs, security services. Potentially easier are also arrangements with external partners (e.g. local government units and external companies) regarding the construction of interchanges and development of facilities. The separation in the structure of PKP Group of the business segment related to passenger service facilities is a tool for more effective management by PKP Group of an area that plays a special social role.

\section{Conclusions}

Changing mobility trends, based primarily on individual motoring, enforce the adjustment of railway stations to new requirements. The quality of services at railway stations can be a decisive factor in the selection of collective transport in relation to the individual. It should be noted that the functioning of railway stations serves not only the business objectives of the railway, but also (and 
perhaps above all) the implementation of the public mission and transport policy of the state. The effects of actions taken by PKP to improve the quality of service at railway stations, will also be consumed by external entities, including local entrepreneurs (e.g. carriers, trade) and local government units, where the stations are located, as well as the general public, thanks to improved transport accessibility of the locality and reduction of pollution and congestion caused by passenger cars. Station railway investments lead to increased accessibility of public transport for all users, in particular for people with reduced mobility. In order to achieve the target standard of passenger services, an integrated approach to the shaping and operation of interchanges should be adopted, consistent with the common perception of railway stations as a logical whole with platforms, routes to access them and the immediate surroundings. This means ceasing to designate areas of responsibility for the passenger station and its surroundings solely on the basis of the ownership title held. Following the discussed foreign practices, the integration of passenger station management can take the form of a dedicated entity managing the entire travel service area.

\section{References}

Allianz pro Schiene website, https://www.allianz-pro-schiene.de/presse/pressemitteilungen/ marburg-und-obstfelderschmiedelichtenhain-sind-sieger/ (access: 20.02.2018).

Badanie satysfakcji z podróży w pociagach PKP Intercity, report on the $6^{\text {th }}$ stage of the study, Millward Brown, Warsaw 2015.

COMMISSION REGULATION (EU) No 1300/2014 of 18 November 2014 on the technical specifications for interoperability relating to the availability of the Union's rail system for people with disabilities and persons with reduced mobility (L series of journals in the European Union No 356 from 12 December 2014).

Internal materials of PKP S.A.

Jakościowe badanie eksploracyjne użytkowników dworców, Millward Brown, Warsaw 2014.

Projektowanie uniwersalne. Ekspertyza w zakresie dostępności kolejowych obiektów obstugi podróżnych z niepetnosprawnościami oraz ograniczona możliwościa poruszania się, Office of Rail Transport, Warsaw 2017.

Public Transport Portal, http://www.transport-publiczny.pl/wiadomosci/polski-bus-od-startu-przewiozl-20-mln-pasazerow-53504.html (access: 20.02.2018).

Rocznik statystyczny Rzeczypospolitej Polskiej 2017, Central Statistical Office, Warsaw 2017.

We build and operate train stations!, DB Station \& Service AG presentation material, 2015.

\section{Corresponding authors}

Mirosław Antonowicz can be contacted at: miroslaw.antonowicz@pkp.pl

Tomasz Moś can be contacted at: tomasz.mos@pkp.pl 